\title{
Koncepcja dobra wspólnego według Jana Pawła II - implikacje dla zbiorowego prawa pracy
}

\author{
Życie społeczne i ekonomiczno-społeczne \\ jest z pewnością rodzajem "naczyń połaczonych" - \\ $i$ do tego rodzaju musi też stosować się \\ wszelka działalność społeczna mająca na celu \\ zabezpieczenie uprawnień każdej z grup. \\ W tym znaczeniu działalność zwią ków zawodowych \\ wkracza niewatpliwie w dziedzine "polityki" \\ rozumianej jako roztropna troska o dobro wspólne.
}

Jan Pawet II: Laborem exercens (20).

\section{Wprowadzenie}

C aproszona do uhonorowania Pana Profesora Michała Seweryńskiego $\checkmark$ księga jubileuszowa, za co serdecznie dziękuję, poszukiwałam tematu nawiązującego do badań naukowych Szanownego Jubilata. Jednym z tych obszarów jest niewątpliwie zbiorowe prawo pracy $^{1}$, w szczególności jego kształt i efektywność ${ }^{2}$.

* Dr hab. prof. nadzw., Katedra Prawa Pracy, Wydział Prawa i Administracji Uniwersytetu Łódzkiego.

${ }^{1}$ Por. m.in. M. Seweryński, Problemy legislacyjne zbiorowego prawa pracy, [w:] Prawo pracy RP w obliczu przemian, red. M. Matey-Tyrowicz, T. Zieliński, Warszawa 2006, s. 381-435; idem, Pojęcie, zakres i próba kodyfikacji zbiorowego prawa pracy w Polsce, [w:] Aktualne problemy zbiorowego prawa pracy w Polsce i w Niemczech, red. G. Goździewicz, Toruń 2012, s. 15-25.

${ }^{2}$ M. Seweryński, Problemy rekodyfikacji prawa pracy, [w:] Prawo pracy a wyzwania XXI wieku. Ksiegga jubileuszowa Profesora Tadeusza Zielińskiego, red. M. Matey-Tyrowicz, L. Nawacki, B. Wagner, Warszawa 2002, s. 319-337; idem, Uwagi o efektywności prawa pracy, [w:] Księga pamiatkowa w piata rocznice śmierci Profesora Andrzeja Kijowskiego, red. Z. Niedbała, Warszawa 2010, s. 271281; idem, Dylematy prawnej ochrony pracy, [w:] Z zagadnień prawa pracy i prawa socjalnego. Ksiegga jubileuszowa Profesora Herberta Szurgacza, red. Z. Kubot, T. Kuczyński, Warszawa 2011, s. 218-227. 
Biorąc to pod uwagę, jak również wskazaną przez organizatorów jubileuszu tematykę księgi odnoszącą się do przyszłości prawa pracy, chciałabym się wypowiedzieć w kwestii koncepcji dobra wspólnego według Jana Pawła II i jej implikacji dla zbiorowego prawa pracy.

Połączenie kategorii aksjologicznej i filozoficznej, jaką jest dobro wspólne, z konstrukcjami prawnymi, jest, jak się wydaje, nie tylko w pełni usprawiedliwione, ale także praktycznie użyteczne. Nie ulega bowiem wątpliwości, że refleksja aksjologiczna w określonym obszarze rzeczywistości, w tym wypadku w prawodawstwie, pozwala nie tylko rozpoznać wartości tej rzeczywistości, ale także przypisać im istotne cele teoretyczne i praktyczne ${ }^{3}$.

Prawo pracy czerpie wartości z różnych prądów filozoficznych, jak również z dorobku społecznej nauki Kościoła ${ }^{4}$. Antycypując dalsze rozważania, należy stwierdzić, że wśród tych wartości jest także idea dobra wspólnego, do której odwołują się już starożytni filozofowie, a także współczesne dokumenty Kościoła katolickiego, w tym papieskie encykliki społeczne. Kategoria dobra wspólnego jest także kategorią prawną występującą w szczególności w prawie konstytucyjnym ${ }^{5}$, natomiast $\mathrm{w}$ prawie pracy próbuje się ją odczytać m.in. w uregulowaniach dotyczących wzajemnej lojalności stron stosunku pracy czy też w uregulowaniach odnoszących się do zasad prowadzenia rokowań i sporów zbiorowych ${ }^{6}$. Wydaje się, że wszystko to upoważnia do podjęcia wskazanego tematu i postawienia tezy, że koncepcja dobra wspólnego jest (powinna być) istotną inspiracją dla instytucji zbiorowego prawa pracy.

${ }^{3}$ W. Słomski, Wielkość aksjologii: bogactwo czy zagrożenie?, [w:] Aksjologia współczesności. Problemy i kontrowersje, red. B. Truchlińska, Lublin 2012, s. 40-43.

4 Zwraca na to uwagę T. Zieliński, Podstawy rozwoju prawa pracy, "Zeszyty Naukowe Uniwersytetu Jagiellońskiego". Prace pracownicze, z. 120 [Kraków] 1988, s. 26; por. także T. Wyka, W poszukiwaniu aksjologii prawa pracy - o roli encykliki "Laborem exercens" Jana Pawta II, „Monitor Prawa Pracy” 2011, nr 9.

${ }^{5}$ Por. art. 1 i 82 Konstytucji RP z 1997 r. Szerzej na ten temat m.in.: G. Kryszeń, Dobro wspólne jako wartość konstytucyjna, [w:] Z aktualnych zagadnień prawa pracy i zabezpieczenia społecznego. Ksiega jubileuszowa Profesora Waleriana Sanetry, red. B. Cudowski, J. Iwulski, Białystok 2013, s. 180-194; M. Piechowiak, Dobro wspólne jako fundament polskiego porzadku konstytucyjnego, Warszawa 2012 i cytowana tam literatura.

${ }^{6}$ Po raz pierwszy w doktrynie prawa pracy szerzej zwraca uwagę na rolę dobra wspólnego w uregulowaniach prawa pracy A. Sobczyk, Prawo pracy w świetle Konstytucji $R P$, t. I, Warszawa 2013, s. 123-137; por. także: P. Grzebyk, Realizacja dobra wspólnego przez przepisy prawa pracy, „Monitor Prawa Pracy” 2011, nr 12, s. 573-576 (pierwotna wersja tego tekstu została włączona do pracy zbiorowej: Dobro wspólne. Teoria i praktyka, red. W. Arnolt, ks. F. Longchamp de Bérier, Warszawa 2013, s. 329-339). 


\section{Różne koncepcje dobra wspólnego}

Istnieje wiele wypowiedzi na temat dobra wspólnego. Biorąc jednak pod uwagę wyżej zakreślony przedmiot rozważań, obejmujący analizę określonych wartości w kontekście uregulowań prawnych, istotnie porządkującą refleksją jest wskazanie dwóch zasadniczo odmiennych koncepcji dobra wspólnego, określonych mianem koncepcji klasycznej i etatystycznej ${ }^{7}$.

Koncepcja klasyczna wywodzi się od Platona i Arystotelesa, a współcześnie jest reprezentowana w społecznej nauce Kościoła katolickiego. W świetle tej koncepcji dobro wspólne jest zasadniczym celem działań wspólnoty, dobrem wspólnym jest to, co służy człowiekowi. Natomiast koncepcja etatystyczna, ukształtowana $\mathrm{w}$ dobie odrodzenia, głównie w filozofii Niccolò Machiavellego, dobro wspólne utożsamia z państwem, dobrem tym jest to, co służy państwu. Stąd też w koncepcji klasycznej uznaje się przyrodzone i niezbywalne prawa człowieka, których ochronie państwo ma służyć, według zaś koncepcji etatystycznej to państwo i prawo są pierwotne, a prawa i wolności są nadane przez państwo, są więc wtórne ${ }^{8}$.

Przyjrzyjmy się nieco bliżej klasycznej koncepcji dobra wspólnego. Według Platona wszystkie instytucje w państwie mają jeden nadrzędny cel, tj. dobro wspólne całej społeczności, władza służy wspólnocie, w której obywatele mogą rozwijać swoje cnoty i osiągnąć spełnienie ${ }^{9}$. Myśl platońską rozwija jego uczeń Arystoteles. Uważa on, że dobre rządy są składową dobra wspólnego, a rolą obywatela jest troska o dobro wspólne, którym jest dobre i szczęśliwe życie ${ }^{10}$.

Z poglądów tych wywodzi się katolicka koncepcja dobra wspólnego. W pierwszej kolejności należy odwołać się do św. Augustyna. Rozumiał on dobro wspólne jako pokój społeczny, „pokój i uporządkowanie zgo$\mathrm{dy}^{\prime \prime 11}$. Wypowiadał się szeroko na temat Państwa i stwierdził, że to samo prawo moralne obowiązuje zarówno Państwo, jak i jednostki. Widział porządek społeczny jako dobro opierające się na wolnej osobie ludzkiej i wspólnym dążeniu do celów moralny ch $^{12}$. Zasadniczo jednak dopiero św.

7 M. Piechowiak, Prawne a pozaprawne pojęcia dobra wspólnego, [w:] Dobro wspólne. Teoria i praktyka..., s. 24-25.

8 Ibidem, s. 26.

9 Z. Stawrowski, Dobro wspólne a filozofia polityki, [w:] Dobro wspólne. Teoria i prakty$k a \ldots$, s. 17-18.

10 Ibidem, s. 20.

11 Podaję za: J.F. Godlewski, Katolicka myśl kościelna o prawie i państwie, Warszawa 1985, s. 120; por. także: ks. J. Gocko, Dobro wspólne, [w:] Jan Paweł II, Encyklopedia nauczania moralnego, red. ks. J. Nagórny, ks. K. Jeżyna, Radom 2005, s. 149.

${ }^{12}$ F. Copleston, Historia filozofii, t. II, Warszawa 2000, s. 85. 
Tomasz z Akwinu rozwinął koncepcję dobra wspólnego. Jak podają badacze jego pism, w dziele: Summa Teologiczna posłużył się pojęciem dobra wspólnego aż 343 razy $^{13}$. Filozof ten zbudował w istocie dwie koncepcje dobra wspólnego, tj. koncepcję dobra wspólnego jako ładu wszechświata oraz koncepcję dobra wspólnego określonych społeczności ludzkich ${ }^{14}$. W ramach pierwszej z nich Bóg jest wspólnym dobrem najwyższym, w ramach drugiej to porządek społeczny zespalający działalność poszczególnych jednostek, prowadząc je do szczęścia, jest dobrem wspólnym ${ }^{15}$. Według Tomasza z Akwinu: „działania są zawsze jednostkowo-szczegółowe, ale takie właśnie działanie można odnieść do dobra wspólnego, które jest wspólne, lecz nie w [taki] sposób jak wspólny jest gatunek lub rodzaj, ale jak wspólna jest przyczyna celowa i dlatego dobrem wspólnym można nazwać wspólny cel"16.

Filozof ten postulował, aby instytucje państwowe liczyły się z dobrem wspólnym wynikającym z nakazów prawa naturalnego ${ }^{17}$. Swięty Tomasz uważał, że ten, kto dąży do dobra wspólnego wszystkich, dąży także do własnego dobra, ponieważ nie można osiągnąć własnego dobra, o ile nie osiągnie się dobra wspólnego, choć stwierdza także, że według sądu prawego rozumu dobro wspólne jest czymś doskonalszym niż dobro jednostki ${ }^{18}$.

W katolickiej nauce społecznej koncepcja dobra wspólnego rozwinęła się dopiero w drugiej połowie XX w. Według Encyklopedii Katolickiej, dobro wspólne to: „wartość zbiorowa wynikająca z wrodzonych zadatków natury człowieka, obejmująca doskonałość osób, którą osiągają one we wzajemnym współżyciu i współdziałaniu poprzez korzystanie ze społecznych urządzeń i środków"19, w świetle zaś Powszechnej Encyklopedii Filozofii dobro wspólne jest definiowane jako „podstawowy czynnik życia społecznego, motywujący działania społeczne osób tworzących daną społeczność, dobro które jest rzeczywistym celem każdego człowieka i zarazem całej społeczności" ${ }^{20}$.

${ }^{13}$ Podaję za: J. Majka, Filozofia społeczna, Wrocław 1982, s. 155.

14 Ibidem, s. 159.

15 Ibidem, s. 160.

${ }^{16}$ Podaję za: H. Piluś, Własność i zasady w katolickiej myśli społecznej, Warszawa 2008, s. $173-174$.

17 J.F. Godlewski, Katolicka..., s. 120; por. także: M. Mrozek OP, Dobro wspólne wczoraj i dziś. Na marginesie lektury Etyki Nikomachejskiej i Summy Teologii, [w:] Dobro wspólne. Teoria i praktyka..., s. 46 i nast.

${ }_{18}$ F. Copleston, Historia filozofii, t. II, s. 377.

19 J. Krucina, Dobro wspólne, [w:] Encyklopedia Katolicka, t. III, Lublin 1985, s. 1379; por. idem, Dobro wspólne. Teoria i jej zastosowanie, Wrocław 1972.

${ }^{20}$ M.A. Krąpiec, Dobro wspólne, [w:] Powszechna Encyklopedia Filozofii, t. II, Lublin 2001, s. 628. 
Na kanwie tych definicji zbudowano współcześnie kilka koncepcji dobra wspólnego ${ }^{21}$, wśród których na szczególną uwagę zasługuje koncepcja realistyczna (lub inaczej prosonalistyczna), powstała na gruncie filozofii klasycznej, a współcześnie rozwijana m.in. przez J. Maritaina, M.A. Krąpca oraz K. Wojtyłę $e^{22}$. Według tej koncepcji celem wszelkich działań indywidualnych i zbiorowych pozostaje człowiek jako osoba i jego dobro. Temu też dobru wspólnemu wszystko ma służyć - urządzenia, instytucje społeczne i rzeczy materialne - nigdy na odwrót.

Kategoria dobra wspólnego występuje także w oficjalnych dokumentach Kościoła katolickiego, w tym w encyklikach papieskich: Rerum novarum Leona XIII, Divisi Illius Magistri i Qudragesimo anno Piusa XI, Matei et magistra i Pacem in terris Jana XXIII, Populorum progresio Pawła VI oraz w kilku encyklikach Jana Pawła II (o czym w dalszej części tego artykułu).

Wyjaśnienie istoty dobra wspólnego odnajdujemy w dokumentach soborowych. Należy zwrócić uwagę na Konstytucję duszpasterska o Kościele w świecie wspótczesnym (Guadium et spes z 7 grudnia 1965 r.), w której zdefiniowano dobro wspólne jako „sumę tych warunków życia społecznego, które pozwalają bądź to grupom, bądź poszczególnym jego członkom pełniej i szybciej osiągnąć własną doskonałość" 23 . Także w Katechizmie Kościoła Katolickiego ogłoszonym przez Jana Pawła II dnia 11 października 1992 r. ${ }^{24}$ znalazł się w części trzeciej, pkt II zatytułowany Dobro wspólne, w którym bardzo szeroko wypowiedziano się na ten temat, określając m.in. "trzy centralne elementy", na których opiera się dobro wspólne, tj. poszanowanie osoby jako takiej, dobrobyt społeczny i rozwój społeczności oraz pokój, czyli trwałość i bezpieczeństwo sprawiedliwego porządkuª ${ }^{25}$. Katechizm odnosi dobro wspólne do wszystkich i od każdego wymaga w tym względzie „roztropności” 26 ; jednakże do państwa „należy obrona i popieranie dobra wspólnego społeczności cywilnej, obywateli i instytucji pośrednich" ${ }^{27}$. Według tego dokumentu dobro wspólne jest wartością

${ }^{21}$ ks. K. Gryżenia (SDB) wyróżnia koncepcję: instrumentalno-instytucyjna, esencjalną, genetyczno-ewolucyjną i przyczynowo-finalistyczną (realistyczną): Dobro wspólne - rozwój osobowy - życie gospodarcze, „Annales. Etyka w życiu gospodarczym” [Łódź] 2007, t. X, nr 2, s. 121-124; por. także różne koncepcje dobra wspólnego zawarte w pracy. J. Krucina, Dobro wspólne. Teoria i jej zastosowanie, Wrocław 1972, s. 217 i nast.

${ }^{22}$ ks. K. Gryżenia SDB, Dobro wspólne..., s. 13.

${ }^{23}$ Konstytucja duszpasterska o Kościele w świecie wspótczesnym, KDK 26; por. także: abp. J. Bolonek, Konstytucja Gaudium et spes - 30 lat dialogu ze światem, „Łódzkie Studia Teologiczne" 1996, nr 5, s. 3 i nast.

${ }^{24}$ Konstytucja Apostolska: Fidei Despositum, [w:] Katechizm Kościoła Katolickiego, Poznań 1994, s. 5-9.

${ }_{25}$ Katechizm Kościoła Katolickiego, 1906-1909.

${ }^{26}$ Katechizm Kościoła Katolickiego, 1906.

${ }_{27}$ Katechizm Kościoła Katolickiego, 1910. 
przypisywaną także „instytucjom pośrednim”, uznawanym przez Jana Pawła II za uczestniczące w urzeczywistnianiu dobra, o czym szerzej w dalszej części pracy.

Z kolei według innego dokumentu, opracowanego na polecenie Jana Pawła II w 2004 r., tj. Kompendium nauki społecznej Kościoła ${ }^{28}$, „dobro wspólne nie jest prostą sumą partykularnych dóbr każdego podmiotu w wymiarze społecznego organizmu. Należąc do wszystkich i do każdego, dobro to jest i pozostaje wspólne, ponieważ jest niepodzielne i można je osiągnąć, pomnażać i chronić tylko razem, także z uwagi na przyszłość" ${ }^{\prime 29}$.

Zauważa się jednakże, że aby dobro, będące motywem i celem działania ludzkiego, było uznane za wspólne, musi być „redystrybuowalne”, tzn. powinno być "rozdawane” między członków społeczności, powinno odznaczać się godziwościa, czyli musi być dobre w znaczeniu moralnym, w szczególności zaś powinno spełniać wymogi sprawiedliwości ${ }^{30}$.

\section{Koncepcja dobra wspólnego według Jana Pawła II}

Wypowiedzi Jana Pawła II na temat dobra wspólnego pojawiają się już w jego dziele Osoba i czyn, opublikowanym w 1969 r., gdzie pisze, że dobrem wspólnym jest nie tylko cel działania, ale głównie to, co wyzwala uczestnictwo we wspólnych działaniach, dobro wspólne traktuje jako dobro uczestnictwa ${ }^{31}$.

Kategoria dobra wspólnego bardzo często pojawia się też w encyklikach Jana Pawła II. Szeroko wypowiada się on na temat roli dobra wspólnego w encyklice Redemptor hominis (1979 r.), w części zatytułowanej: Prawa człowieka: „Litera” czy "Duch". Stwierdza tam jednoznacznie, że: „Kościół zawsze uczył obowiązku działania dla dobra wspólnego, przez to starał się wychowywać dobrych obywateli w każdym państwie. Kościół także uczył, że podstawowym obowiązkiem władzy jest troska o dobro wspólne społeczeństwa: stąd wynikają jej zasadnicze uprawnienia. Ale właśnie w imię tych założeń obiektywnego porządku etycznego, uprawnienia władzy nie mogą być rozumiane inaczej, jak tylko na zasadzie poszanowania obiektywnych i nienaruszalnych praw człowieka.

${ }^{28}$ Por.: Przedmowa do Kompendium nauki społecznej Kościoła, [w:] Papieska Rada Justitia et PAX: Kompendium nauki społecznej Kościoła, Kielce 2005, s. XIII-XIV.

${ }_{29}$ Zasada dobra wspólnego, [w:] Kompendium Nauki Społecznej Kościoła..., s. 109.

${ }^{30}$ ks. J. Kora, Dobro wspólne fundamentalna zasada działalności charytatywnej Kościoła, [w:] Człowiek - Kościót - Świat. Katolicka myśl społeczna u progu III tysiąclecia, red. J. Wojciechowski, Łódź 2002, s. 270-271; podobnie idem, Dobro wspólne, [w:] Jan Paweł II, Encyklopedia nauczania społecznego, red. ks. A. Zwoliński, Radom 2005, s. 116.

${ }^{31}$ K. Wojtyła, Osoba i czyn, Kraków 1969, s. 308. 
Tylko wówczas bowiem owo dobro wspólne, któremu służy w państwie władza, jest w pełni urzeczywistnione, kiedy obywatele mają pewność swoich praw" (RH 17) ${ }^{32}$.

Jak z tego wynika, w encyklice dobro wspólne jest analizowane głównie w kontekście powinności państwa ${ }^{33}$.

W encyklice Dives in misericordia (1980 r.) $)^{34}$ Jan Paweł II ukazuje w sposób niezwykle dramatyczny niepokoje i zagrożenia współczesnego człowieka (DM 11). „Musi niepokoić upadek wielu wartości..., czysto utylitarny stosunek do człowieka, zatrata poczucia prawdziwego dobra wspólnego i łatwość z jaką ulega ono alienacji" (DM 12). Dobro wspólne zostaje tu przedstawione jako zagrożona wartość międzyludzka.

Temat dobra wspólnego został także podjęty w encyklice Laborem exercens $\left(1981 \mathrm{r}\right.$.) ${ }^{35}$. Jan Paweł traktuje dobro wspólne m.in. jako przesłankę uspołecznienia środków produkcji. Owo uspołecznienie powinno się dokonać przy udziale „organizmów pośrednich o celach gospodarczych, społecznych, kulturalnych, które cieszyłyby się rzeczywistą autonomią w stosunku do władz publicznych; dążyłyby one do sobie właściwych celów poprzez lojalną współpracę, przy podporządkowaniu wymogom wspólnego dobra" (LE 14).

Dobro wspólne staje się więc granicą i jednocześnie celem działania owych organizmów pośrednich, w szczególności takim celem może być partycypacja ${ }^{36}$, a organizmy te mogą przybierać formę "stowarzyszeń lub związków mających na celu obronę żywotnych interesów ludzi zatrudnionych" (LE 20).

Uznając prawo związków zawodowych do walki o słuszne uprawnienia ludzi pracy, Jan Paweł II zauważa, że „walka ta winna być traktowana jako normalne staranie o właściwe dobro [...], nie powinna być to być natomiast walka przeciwko innym" i w tym kontekście nawołuje związki

${ }^{32}$ Jan Paweł II, Encyklika Redemptor hominis, [w:] Encykliki Ojca Świętego bł. Jana Pawta II, Kraków (brak roku wydania), s. 5 i nast.

${ }^{33}$ Podobnie wypowiedział się na temat dobra wspólnego w homilii wygłoszonej w roku 1987 w Gdańsku. Stwierdził wówczas: „Jednym z ważnych zadań państwa jest stwarzanie przestrzeni dla każdego, tak aby każdy mógł przez pracę rozwijać siebie, swoją osobowość [...] Ta przestrzeń osoby w życiu społecznym jest równocześnie warunkiem dobra wspólnego. Jeśli człowiekowi odbiera się te możliwości, jeżeli organizacja życia zbiorowego zakłada zbyt ciasne ramy dla ludzkich możliwości - to jest [...] przeciw jego dobru - przeciw dobru wspólnemu" (Jan Paweł II, Pielgrzymki do Ojczyzny: 1979, 1983, 1987, 1991, 1995, 1997. Przemówienia, homilie, Kraków 1997, s. 494).

34 Jan Paweł II, Encyklika Dives in misericordia, [w:] Encykliki Ojca Świętego..., s. 49 i nast.

35 Jan Paweł II, Encyklika Laborem exercens, [w:] Encykliki Ojca Świętego..., s. 87 i nast.

36 Szerzej: T. Wyka, Partycypacja pracownicza w świetle nauczania Jana Pawła II, [w:] Studia z prawa pracy. Księga pamiątkowa ku czci Docenta Jerzego Logi, red. Z. Goral, Łódź 2007, s. 193 i nast. 
zawodowe do „roztropnej troski o dobro wspólne” (LE 20), także w korzystaniu z prawa do strajku, którego nadużywanie, zdaniem Jana Pawła II, „może prowadzić do paraliżowania całego życia społeczno-ekonomicznego, co jest sprzeczne z wymogami dobra wspólnego społeczeństwa" (LE 20). Jan Paweł II postrzega więc dobro wspólne także w kontekście zbiorowych uprawnień pracowniczych i wymaga, aby interesy związkowe nie przesłaniały konieczności dbałości o dobro wspólne; dobro to stawia więc ponad partykularne interesy różnych grup.

Takie też stanowisko zajmuje $\mathrm{w}$ encyklice Sollicitudo rei socialis $(1987 \text { r. })^{37}$, wzywając zarówno „silnych, jak i słabszych” oraz grupy pośrednie do współodpowiedzialności za dobro wspólne. Według Niego: „Praktykowanie solidarności wewnątrz każdego społeczeństwa posiada wartość wtedy, gdy jego członkowie uznają się wzajemnie za osoby. Ci, którzy posiadają większe znaczenie, dysponując większymi zasobami dóbr i usług, winni poczuwać się do odpowiedzialności za słabszych [...] Słabsi ze swej strony, postępując w tym samym duchu solidarności, nie powinni przyjmować postawy czysto biernej lub niszczącej tkankę społeczną, ale dopominając się o swoje słuszne prawa, winni również dawać swój należyty wkład w dobro wspólne. Grupy pośrednie zaś nie powinny egoistycznie popierać własnych interesów, ale szanować interesy drugich" (SRS 39).

Zasadniczym celem tej wypowiedzi Jana Pawła II było podkreślenie współodpowiedzialności wszystkich, całego społeczeństwa, za dobro wspólne.

Pogłębienie rozważań zawartych w Laborem exercens i w Sollicitudo rei socialis, nastąpiło, jak pisze sam Autor, w encyklice Centisimus annus $(1991 \text { r. })^{38}$. Papież szeroko odnosi się tu m.in. do grup pośrednich działających na płaszczyźnie zawodowej i w tym kontekście przedstawia koncepcję przedsiębiorstwa. Przypomina, że społeczna nauka Kościoła „uznaje pozytywny charakter rynku i przedsiębiorstwa, ale jednocześnie wskazuje, że muszą być one nastawione na dobro wspólne" (CA 43). Według Niego „przedsiębiorstwa nie można uważać jedynie za „zrzeszenie kapitałów”, jest ono równocześnie „zrzeszeniem osób”, w skład którego wchodzą w różny sposób i w różnych zakresach odpowiedzialności zarówno ci, którzy wnoszą konieczny do jego działalności kapitał, jak i ci, którzy w tę działalność wnoszą swą pracę" (CA 43).

Ostatecznie więc na poziomie przedsiębiorstwa dobro wspólne ma być dobrem wspólnym dla „kapitału” i dla „osób” w nim pracujących.

${ }^{37}$ Jan Paweł II, Encyklika Sollicitudo rei socialis, [w:] Encykliki Ojca Świętego..., s. 273 i nast.

${ }_{38}$ Jan Paweł II, Encyklika Centisimus annus, [w:] Encykliki Ojca Świętego..., s. 393 i nast.; por. CA 13. 
Przedstawione wyżej wypowiedzi Jana Pawła II na temat dobra wspólnego, zawarte głównie w encyklikach, skłaniają do kilku refleksji. Po pierwsze, ukazuje tę kategorię wielopłaszczyznowo i wielopodmiotowo zarówno jako wartość samą w sobie, wartość osobową i jednocześnie międzyosobowa jak i w odniesieniu do różnych podmiotów, poczynając od państwa, poprzez grupy pośrednie - w tym związki zawodowe, przedsiębiorstwa, aż do pojedynczej osoby. Po drugie, czyni wszystkie te podmioty odpowiedzialnymi za dobro wspólne, stosownie do ich możliwości i zadań. Po trzecie, dobro wspólne według Jana Pawła II jawi się jako kategoria wyzwalająca z egoizmów i partykularnych interesów.

Rozważmy zatem, czy tak rozumiane dobro wspólne jest (powinno być) istotną przesłanką kształtowania zbiorowego prawa pracy.

\section{Dobro wspólne a pojęcie zbiorowego prawa pracy}

Pojęcie zbiorowego prawa pracy nie jest jednolicie rozumiane ${ }^{39}$. Na początku warto przytoczyć tu stanowisko Departamentu Pracy i Opieki Społecznej Delegatury Rządu (1941-1945) na temat założeń zbiorowego prawa pracy. Miało to być: „prawo ludzi pracy wypełniające pustkę prawną między indywidualnymi umowami o pracę a prawem stanowionym przez państwo. Jako pochodzące ze współdziałania [...] pracowników i pracodawców [...] miało zapewniać dobieranie trafnych form [...], elastycznych i dostosowanych do rzeczywistości [...], miało służyć realizacji sprawiedliwości społecznej" ${ }^{\prime 4}$.

W założeniach tych dostrzegamy dylematy zbiorowego prawa pracy podnoszone współcześnie. Ciągle rozważa się bowiem jego miejsce w relacji do indywidualnego prawa pracy, przedmiot, a także cele. Obecnie zbiorowe prawo pracy definiuje się najczęściej jako część prawa pracy obejmującą przepisy regulujące status zbiorowych podmiotów prawa pracy: związków zawodowych i załóg pracowniczych oraz pracodawców i ich organizacji, a także relacje między tymi podmiotami ${ }^{41}$. Relacje te bliżej ukazuje M. Seweryński, wyróżniając powiązania między pracownikami

39 Szeroko na ten temat: B.M. Ćwiertniak, Pojęcie $i$ definiowanie zbiorowego prawa pracy, [w:] System prawa pracy. Zbiorowe prawo pracy, t. V, red. K.W. Baran, Warszawa 2014, s. 25 i nast.

40 W. Szubert, Problemy pracy w koncepcjach programowych Delegatury Rzadu na Kraj (1941-1945), Łódź 2012, s. 104.

${ }^{41}$ Por. m.in. T. Liszcz, Prawo pracy, Warszawa 2014, s. 501; por. także definicję zbiorowego prawa pracy według W. Szuberta, który przyjmuje, że prawo to normuje formy zrzeszenia się i zespołowego działania pracowników oraz ich uczestniczenia w procesie tworzenia prawa i zarządzania zakładami pracy (W. Szubert, Współczesne tendencje przemian w prawie pracy, „Państwo i Prawo” 1981, nr 8, s. 7). 
i pracodawca, organizacjami pracodawców i pracowników, pracodawcą i organizacjami pracowników, organem publicznym a organizacjami pracowników lub pracodawców ${ }^{42}$.

"Zbiorowośćc tego prawa wynika ze zbiorowego charakteru jego podmiotów oraz $\mathrm{z}$ ich ponadindywidualnych, zbiorowych praw i interesów. „Zbiorowe” nie musi przy tym oznaczać „wspólne”. Zbiorowe prawo pracy nie jest bowiem „wspólnym” prawem dla różnych, co do charakteru, podmiotów, ale jest prawem dla podmiotów jednorodnych, bo nie indywidualnych. Nie ma więc prostej zależności między zbiorowym prawem pracy a dobrem wspólnym (zbiorowym). Poszukiwane dobro wspólne ma być „wspólnym mianownikiem” dla podmiotów zbiorowych, być dla nich „wspólnym dobrym mianownikiem”, bo z samej istoty dobra, jest ono wartością pozytywną. Odkodowanie takiego dobra wspólnego nie jest zadaniem łatwym, jeśli się zauważy, że wskazane wyżej podmioty zbiorowego prawa pracy reprezentują często sprzeczne względem siebie prawa i interesy.

Zdaniem przedstawicieli doktryny zbiorowego prawa pracy opiera się ono „na fundamentalnej dyrektywie kształtowania jego stosunków w sposób umożliwiający równoważenie sił pracy i kapitału"43. Możemy więc przyjąć, że zbiorowe prawo pracy służy osiąganiu kompromisu między interesami pracodawców a interesami pracowników (ich przedstawicieli), kompromisu osiąganego w imię określonego celu, którym jest (powinno być) wspólne dla nich dobro. $Z$ samej więc, tak określonej, istoty zbiorowego prawa pracy, jako prawa będącego wyrazem kompromisu różnych interesów, wynika, że jest ono oparte na kategorii dobra wspólnego, ponadpartykularnego, jak to właśnie przyjmował Jan Paweł II w wielu wyżej cytowanych wypowiedziach. W szczególności przedstawiona przez niego koncepcja przedsiębiorstwa będącego zrzeszeniem kapitałów i osób, które powinno działać w imię dobra wspólnego, stanowi istotne przesłanie dla zbiorowego prawa pracy. I tak też jest ono odczytywane obecnie, jeśli uważa się, że „,współczesny zakład pracy należy traktować jako wspólne dobro pracodawcy i zatrudnionych w nim pracowników" ${ }^{\prime 4}$.

Pozostaje jednak do rozważenia, w imię jakiego celu, jakiego dobra wspólnego, ów kompromis jest w zbiorowym prawie pracy zakładany i realizowany. Uważa się, że celem zbiorowego prawa pracy jest „stabi-

${ }_{2}^{42}$ M. Seweryński, Pojęcie, zakres i próba kodyfikacji zbiorowego prawa pracy w Polsce..., s. $19-20$.

${ }^{43}$ Z. Hajn, Zbiorowe prawo pracy. Zarys systemu, Warszawa 2013, s. 31 i cytowana tam literatura.

${ }^{44}$ G. Goździewicz, Tendencje przemian w zbiorowym prawie pracy w Polsce, [w:] Ład społeczny w Polsce i w Niemczech na tle jednoczacej się Europy. Księga pamiątkowa poświęcona Czesławowi Jackowiakowi, red. B. von Maydell, T. Zieliński, Warszawa 1999, s. 79. 
lizacja państwa i gospodarki oraz zapewnienie pokoju społecznego" ${ }^{45}$, co może także potwierdzać sformułowany przez M. Seweryńskiego pogląd, że zbiorowe prawo pracy odgrywa ważną rolę w stosunkach politycznych, gospodarczych i społecznych ${ }^{46}$, jak również stanowisko W. Szuberta, że jest to gałąź prawa „o dużej doniosłości społecznej”"47. Owa doniosłość społeczna wyraża się również w tym, że zbiorowe prawo pracy wykazuje liczne cechy wspólne z polityką społeczną w szczególności opiera się na podobnych uwarunkowaniach, to jest na szeroko rozumianym poczuciu bezpieczeństwa ${ }^{48}$, określonego na gruncie zbiorowego prawa pracy mianem pokoju społecznego.

Tak określone ratio legis, cel zbiorowego prawa pracy, jako służące stabilizacji państwa i gospodarki oraz zapewnieniu pokoju społecznego, jest tym poszukiwanym dobrem wspólnym. Warto w tym miejscu zauważyć, że w projekcie zbiorowego kodeksu pracy obowiązek poszanowania pokoju społecznego jest traktowany jako podstawowa zasada zbiorowego prawa pracy ${ }^{49}$. Płaszczyzny realizacji tego dobra należy upatrywać zarówno w relacjach podmiotów zbiorowych z państwem (stabilizacja państwa i gospodarki), jak i między tymi podmiotami na płaszczyźnie zakładu pracy. I takie też różne płaszczyzny realizacji dobra wspólnego, jako wartości samej w sobie, widzi Jan Paweł II, o czym była mowa wyżej.

\section{Instytucje zbiorowego prawa pracy służące zapewnieniu pokoju społecznego}

Określenie wartości, na której zbudowane jest zbiorowe prawo pracy, będącej owym dobrem wspólnym dla podmiotów zbiorowych, wymaga następnie wskazania instytucji służących jego realizacji i pomnażaniu. Pomocne $\mathrm{w}$ tym względzie będzie odwołanie się do funkcji zbiorowego prawa pracy.

W doktrynie dokonuje się różnych klasyfikacji tych funkcji. K.W. Baran, opierając się głównie na kryterium podmiotowym, wyróżnia funkcję ochronną zbiorowego prawa pracy adresowaną do ogółu pracowników, funkcję organizatorską służącą ochronie interesów pracodawców, funkcję gwarancyjną kierowaną do związków zawodowych i organizacji

\footnotetext{
${ }^{45}$ Ibidem, s. 32.

${ }^{46}$ M. Seweryński, Problemy legislacyjne zbiorowego prawa pracy..., s. 384.

47 W. Szubert, Wspótczesne tendencje..., s. 7.

48 J. Piątkowski, Polityka społeczna a zbiorowe prawo pracy, [w:] System prawa pracy, t. V, s. 101 i nast.

${ }^{49}$ Komisja Kodyfikacyjna Prawa Pracy: Kodeks pracy. Zbiorowy kodeks pracy. Projekty, Katowice 2010; por. także: M. Seweryński, Problemy legislacyjne zbiorowego..., s. 384-385.
} 
pracodawców oraz funkcję porządkową w odniesieniu do państwa i obywateli ${ }^{50}$. Zaletą tej klasyfikacji jest to, że wskazuje ona na adresatów realizacji dobra wspólnego, poczynając od pracowników i ich przedstawicieli, poprzez pracodawców i ich reprezentantów, aż po wskazanie państwa i całego społeczeństwa, zobowiązanych do zapewnienia pokoju społecznego. Odnajdujemy w tym istotną myśl Jana Pawła II o obowiązku i odpowiedzialności każdego z osobna i wszystkich razem za dobro wspólne.

Z punktu widzenia postawionego wyżej celu, to jest wskazania instytucji zbiorowego prawa pracy służących zapewnieniu pokoju społecznego, klasyfikacja ta nie jest jednak w pełni przydatna. Celowi temu posłuży lepiej klasyfikacja przyjęta przez Z. Hajna, który wyróżnia funkcje zbiorowego prawa pracy, jak to sam określa, na płaszczyźnie „instrumentalnej", utożsamiając je ze szczegółowymi celami zbiorowego prawa pracy. Po pierwsze wskazuje na regulowanie przez zbiorowe prawo pracy różnych metod uzgadniania przez pracodawców i przedstawicieli pracowników warunków pracy; po drugie na zapewnienie partnerom społecznym wpływu na politykę państwa w szeroko rozumianej sferze socjalnej oraz, po trzecie, wyodrębnia funkcję (cel) zbiorowego prawa pracy zapewnienia pracownikom wpływu na zarządzanie zakładem pracy ${ }^{51}$.

Wydaje się, że wspólną instytucją dla tych trzech instrumentalnych funkcji zbiorowego prawa pracy jest instytucja dialogu społecznego, będącego środkiem do osiągania i gwarantowania pokoju społecznego. $\mathrm{Na}$ gruncie prawa pracy dialog ten jest przez M. Seweryńskiego określany mianem „społecznego dialogu pracy" 52 , co z jednej strony wskazuje na jego znaczenie dla ustroju pracy ${ }^{53}$ z drugiej zaś oznacza, że może to być instytucja wykraczająca poza prawo pracy (w tym zbiorowe prawo pracy), istotna także w innych dziedzinach ${ }^{54}$.

Nie ulega jednak wątpliwości, że instytucja dialogu społecznego odgrywa szczególne znaczenie $\mathrm{w}$ obszarze zbiorowego prawa pracy, gdzie jest kwalifikowana jako narzędzie tego prawa ${ }^{55}$, jako jego podstawowa za-

${ }^{50}$ K.W. Baran, Funkcje zbiorowego prawa pracy, [w:] System prawa pracy, t. V, s. 129 i nast.

51 Z. Hajn, Zbiorowe prawo pracy..., s. 32-33.

${ }^{52}$ M. Seweryński, Dialog społeczny, [w:] Referaty na VI Europejski Kongres Prawa Pracy i Zabezpieczenia Społecznego, Warszawa 1999, s. 20 i 38; por. także: R. Blanpain, Dialog społeczny. Wspótzależność gospodarcza i prawo pracy, [w:] Referaty na VI Kongres..., s. 39 i nast.

${ }_{53}$ Por. m.in.: W. Sanetra, Dialog społeczny jako element ustroju społecznego i politycznego w świetle Konstytucji RP, [w:] Zbiorowe prawo pracy XXI wieku, red. A. Wypych-Żywicka, M. Tomaszewska, J. Stelina, Gdańsk 2012, s. 9 i nast.

${ }^{54}$ Por. m.in. J. Gadowski, Na dwudziestolecie dialogu społecznego w Polsce, [w:] Zbiorowe prawo pracy w XXI wieku..., s. 30 i nast.; Abp. R. Marx, Kapitał. Mowa w obronie człowieka, Kraków 2009, s. 51, 61, 77; M.J. Sandel, Sprawiedliwość. Jak postępować słusznie?, Warszawa 2013, s. 352-355.

${ }_{55}$ A. Sobczyk, A. Daszyńska, Dialog społeczny jako narzędzie zbiorowego prawa pracy, [w:] Dialog społeczny w praktyce przedsiębiorstw, red. J. Stelina, Gdańsk 2010, s. 9 i nast. 
sada $^{56}$, mająca umocowanie konstytucyjne w art. 20 Konstytucji RP z 1997 r., w świetle którego solidarność, dialog i współpraca partnerów społecznych stanowią podstawę ustroju gospodarczego Rzeczypospolitej Polskiej ${ }^{57}$.

Istnieje bardzo wiele wypowiedzi na temat dialogu społecznego. Biorąc pod uwagę cel naszych rozważań, poświęconych wartościom, na których opiera się zbiorowe prawo pracy, szczególnie istotne jest postawienie pytania, czy dialog społeczny jest jedynie instrumentem służącym rozwiązaniu konfliktów między podmiotami zbiorowego prawa pracy, czy też służy osiągnięciu pokoju społecznego jako dobra wspólnego dla wszystkich tych podmiotów ${ }^{58}$. Jest to pytanie fundamentalne, dotyczące ideologii zbiorowego prawa pracy, a mianowicie czy opiera się ono na założeniu sprzeczności interesów, czy jednak na wspólnocie tych interesów ${ }^{59}$. Odpowiedź na to pytanie przesądza w dużym stopniu o roli prawa w kształtowaniu zbiorowego prawa pracy. Opowiadam się za koncepcją dialogu społecznego jako instrumentu głównie prewencyjnego, służącego zapobieganiu powstawania konfliktów i przez to osiaganiu pokoju społecznego. Takie stanowisko reprezentuje m.in. M. Seweryński, według którego potencjalnie konfliktowy charakter zbiorowych stosunków pracy nie wyczerpuje istoty tych stosunków. Konflikt interesów jest jedynie pewnym stanem przejściowym, etapem na drodze do osiągnięcia porozumienia ${ }^{60}$, a zatem - dodajmy - na drodze osiągania pokoju społecznego.

Funkcja dialogu społecznego jako środka do osiągnięcia pokoju społecznego jest metafunkcja, pośród innych, które są przypisywane tej instytucji. Wydaje się, że tak też jest postrzegana w doktrynie, skoro wymienia się ją na pierwszym miejscu wśród różnych szczegółowych zasad (funkcji) zbiorowego prawa pracy ${ }^{61}$. Tak też widział stosunki zbiorowego prawa pracy Jan Paweł II uznając walkę o uprawnienia ludzi pracy za normalne staranie o „właściwe dobro” (LE 20).

56 W szczególności: E. Wronikowska, Dialog społeczny jako podstawowa zasada zbiorowego prawa pracy w Polsce, [w:] Studia z zakresu prawa pracy i polityki społecznej, red. A. Świątkowski, Kraków 2007; por. także G. Goździewicz, Podstawowe zasady zbiorowego prawa pracy, [w:] Zbiorowe prawo pracy w społecznej..., s. 45-48.

57 Konstytucja RP z dnia 2 kwietnia 1997 r., DzU, 1997, nr 78, poz. 483.

58 Ważne pytania w tej kwestii stawia: M. Gładoch, Dialog społeczny w zbiorowym prawie pracy, Toruń 2014, s. 20-25; por. także: A.M. Świątkowski, Gwarancje prawne pokoju społecznego w stosunkach pracy, Warszawa 2013.

59 T. Zieliński, Zbiorowe spory pracy a współczesne koncepcje ładu społecznego, „Ruch Prawniczy, Ekonomiczny i Socjologiczny" 1984, z. 2, s. 22-30.

${ }^{60}$ M. Seweryński: Dialog społeczny..., s. 13-15; Podobne stanowisko zajmuje M. Gładoch, według której „zasada dialogu społecznego nie jest równoznaczna z teorią bezkonfliktowości" (M. Gładoch, Dialog społeczny..., s. 22).

${ }^{61}$ Por. G. Goździewicz, Podstawowe zasady..., s. 45-47; M. Gładoch, Dialog społeczny..., s. 206-211. 
W przepisach zbiorowego prawa pracy możemy wskazać jednoznaczne potwierdzenie wartości, na której jest ono zbudowane. Ramy niniejszego opracowania nie pozwalają na szerszą wypowiedź w tym zakresie. Niech więc wystarczy przywołanie dwóch uregulowań. Pierwsze dotyczy zasad prowadzenia rokowań w celu zawarcia układu zbiorowego pracy. Zgodnie $\mathrm{z}$ art. $241^{3} \S 1 \mathrm{kp}$, każda ze stron układu powinna je prowadzić $\mathrm{w}$ dobrej wierze, z poszanowaniem słusznych interesów drugiej strony, w szczególności pracodawca winien uwzględniać postulaty organizacji związkowej uzasadnione swa sytuacją ekonomiczna, związki zaś zawodowe powinny powstrzymać się od wysuwania postulatów przekraczających możliwości finansowe pracodawcy. W doktrynie nie ma wątpliwości, że unormowanie to służy osiągnięciu pokoju społecznego, który ma także wymiar ogólnospołeczny ${ }^{62}$.

Układowe zasady prowadzenia rokowań w dobrej wierze i z poszanowaniem słusznych interesów drugiej strony odgrywają rolę „dobrych praktyk" i jako takie należy je stosować przy zawieraniu pozaukładowych porozumień zbiorowych, które również służą zapewnieniu pokoju społecznego ${ }^{63}$.

Drugim przykładem normatywnego potwierdzenia pokoju społecznego jako dobra wspólnego, chronionego zbiorowym prawem pracy, są regulacje dotyczące zasad rozwiązywania sporów zbiorowych, w szczególności zasada wyrażona w art. 4 ust. 2 ustawy z dnia 23 maja 1991 r. o rozwiązywaniu sporów zbiorowych ${ }^{64}$, w świetle której warunkiem legalności sporu zbiorowego (i ewentualnie strajku), w przedmiocie spraw objętych układem zbiorowym pracy lub innym porozumieniem zbiorowym jest ich wypowiedzenie.

W doktrynie wyrażono pogląd, że przepis ten wyraża zasadę pokoju społecznego ${ }^{65}$. Zasada ta leży także u podstaw regulacji zawartej w art. 17 ust. 3 wyżej wskazanej ustawy, wymagającej uwzględniania przy podejmowaniu decyzji o strajku tzw. reguły proporcjonalności, tzn. oceny współmierności żądań do strat związanych ze strajkiem.

${ }^{62}$ J. Wratny, Kodeks pracy - układy zbiorowe pracy, [w:] Zbiorowe prawo pracy, red. J. Wratny, K. Walczak, Warszawa 2009, s. 166; L. Florek, Znaczenie układów zbiorowych pracy, [w:] Układy zbiorowe pracy. W stulecie urodzin Profesora Wactawa Szuberta, red. Z. Góral, Warszawa 2013, s. 50; P. Nowik, Etos partnerów społecznych w praktyce zawierania układów zbiorowych pracy, [w:] Układy zbiorowe pracy. W stulecie..., s. 154-155.

${ }_{63}$ T. Wyka, Znaczenie prawa o układach zbiorowych pracy dla pozaukładowych porozumień zbiorowych, [w:] Prawo pracy. Refleksje i poszukiwania. Księga jubileuszowa Profesora Jerzego Wratnego, Warszawa 2013, s. 146-147.

${ }^{64}$ Ustawa z dnia 23 maja 1991 roku o rozwiązywaniu sporów zbiorowych, DzU, 1991, nr 55, poz. 236 ze zm.

${ }^{65}$ M. Kurzynoga, Warunki legalności strajku, Warszawa 2011, s. 175. 
Z przytoczonych wyżej, przykładowych unormowań jasno wynika, że podmioty zbiorowego prawa pracy są postawione $\mathrm{w}$ roli partnerów, a nie konkurentów. Zatem założoną i pożądaną formą ich działania ma być dialog, nie zaś konfrontacja. Chodzi o dialog służący osiąganiu pokoju społecznego, będący dobrem wspólnym, za które to dobro podmioty owe są współodpowiedzialne.

Przedstawiona wyżej koncepcja dobra wspólnego według Jana Pawła II znajduje tu więc pełne odzwierciedlenie.

\section{Bibliografia}

Baran K.W., Funkcje zbiorowego prawa pracy, [w:] System prawa pracy, t. V, red. K.W. Baran, Warszawa 2014.

Blanpain R., Dialog społeczny. Współzależność gospodarcza i prawo pracy, [w:] Referaty na VI Europejski Kongres Prawa Pracy i Zabezpieczenia Społecznego, Warszawa 1999.

Bolonek J. abp., Konstytucja Gaudium et spes - 30 lat dialogu ze światem, „Łódzkie Studia Teologiczne" 1996, nr 5.

Copleston F., Historia filozofii, t. II, Warszawa 2000.

Ćwiertniak B.M., Pojęcie i definiowanie zbiorowego prawa pracy, [w:] System prawa pracy. Zbiorowe prawo pracy, t. V, red. K.W. Baran, Warszawa 2014.

Florek L., Znaczenie układów zbiorowych pracy, [w:] Układy zbiorowe pracy. W stulecie urodzin Profesora Wactawa Szuberta, red. Z. Góral, Warszawa 2013.

Gadowski J., Na dwudziestolecie dialogu społecznego w Polsce, [w:] Zbiorowe prawo pracy w XXI wieku, red. A. Wypych-Żywicka, M. Tomaszewska, J. Stelina, Gdańsk 2010.

Gładoch M., Dialog społeczny w zbiorowym prawie pracy, Toruń 2014.

Gocko J. ks., Dobro wspólne, [w:] Jan Paweł II, Encyklopedia nauczania moralnego, red. ks. J. Nagórny, ks. K. Jeżyna, Radom 2005.

Godlewski J.F., Katolicka myśl kościelna o prawie i państwie, Warszawa 1985.

Goździewicz G., Podstawowe zasady zbiorowego prawa pracy, [w:] Zbiorowe prawo pracy w społecznej gospodarce rynkowej, red. G. Goździewicz, wyd. TNOiK, Toruń 2000.

Goździewicz G., Tendencje przemian w zbiorowym prawie pracy w Polsce, [w:] Ład społeczny w Polsce i w Niemczech na tle jednoczacej się Europy. Księga pamiątkowa poświęcona Czestawowi Jackowiakowi, red. B. von Maydell, T. Zieliński, Warszawa 1999.

Gryżenia K. ks. (SDB), Dobro wspólne - rozwój osobowy - życie gospodarcze, „Annales. Etyka w życiu gospodarczym" [Łódź] 2007, t. X, nr 2.

Grzebyk P., Realizacja dobra wspólnego przez przepisy prawa pracy, „Monitor Prawa Pracy” 2011, nr 12 [pierwotna wersja tego tekstu została włączona do pracy zbiorowej: Dobro wspólne. Teoria i praktyka, red. W. Arnolt, ks. F. Longchamp de Bérier, Warszawa 2013].

Hajn Z., Zbiorowe prawo pracy. Zarys systemu, Warszawa 2013.

Jan Paweł II, Encyklika Centisimus annus; Encyklika Dives in misericordia; Encyklika Laborem exercens; Encyklika Redemptor hominis, [w:] Encykliki Ojca Świętego bt. Jana Pawła II, Kraków [brak roku wydania].

Jan Paweł II, Encyklika Sollicitudo rei socialis, Watykan 1987.

Jan Paweł II, Pielgrzymki do Ojczyzny, 1979, 1983, 1987, 1991, 1995, 1997. Przemówienia, homilie, Kraków 1997.

Komisja Kodyfikacyjna Prawa Pracy, Kodeks pracy. Zbiorowy kodeks pracy. Projekty, Katowice 2010. 
Konstytucja Apostolska, Fidei Despositum, [w:] Katechizm Kościoła Katolickiego, Poznań 1994. Koral J. ks, Dobro wspólne, [w:] Jan Paweł II, Encyklopedia nauczania społecznego, red. ks. A. Zwoliński, Radom 2005.

Koral J. ks., Dobro wspólne fundamentalna zasada dziatalności charytatywnej Kościoła, [w:] Człowiek - Kościót - Świat. Katolicka myśl społeczna u progu III tysiaclecia, red. J. Wojciechowski, Łódź 2002.

Krąpiec A.M., Dobro wspólne, [w:] Powszechna Encyklopedia Filozofii, t. II, Lublin 2001.

Krucina J., Dobro wspólne, [w:] Encyklopedia Katolicka, t. III, Lublin 1985.

Krucina J., Dobro wspólne. Teoria i jej zastosowanie, Wrocław 1972.

Kryszeń G., Dobro wspólne jako wartość konstytucyjna, [w:] Z aktualnych zagadnień prawa pracy i zabezpieczenia społecznego. Księga jubileuszowa Profesora Waleriana Sanetry, red. B. Cudowski, J. Iwulski, Białystok 2013.

Kurzynoga M., Warunki legalności strajku, Warszawa 2011.

Liszcz T., Prawo pracy, Warszawa 2014.

Majka J., Filozofia społeczna, Wrocław 1982.

Marx R. abp, Kapitat. Mowa w obronie człowieka, Kraków 2009.

Mrozek M. OP, Dobro wspólne wczoraj i dziś. Na marginesie lektury Etyki Nikomachejskiej i Summy Teologii, [w:] Dobro wspólne. Teoria i praktyka, red. W. Arnold, ks. F. Longchamp de Berier, Warszawa 2013.

Nowik P., Etos partnerów społecznych w praktyce zawierania układów zbiorowych pracy, [w:] Układy zbiorowe pracy. W stulecie urodzin Profesora Wactawa Szuberta, red. Z. Góral, Warszawa 2013.

Piątkowski J., Polityka społeczna a zbiorowe prawo pracy, [w:] System prawa pracy, t. V, red. K.W. Baran, Warszawa 2014.

Piechowiak M., Dobro wspólne jako fundament polskiego porządku konstytucyjnego, Warszawa 2012.

Piechowiak M., Prawne a pozaprawne pojęcia dobra wspólnego, [w:] Dobro wspólne. Teoria i praktyka, red. W. Arnolt, ks. F. Longchamp de Berier, Warszawa 2013.

Piluś H., Własność i zasady w katolickiej myśli społecznej, Warszawa 2008.

Przedmowa do Kompendium nauki społecznej Kościoła, [w:] Papieska Rada Justitia et PAX, Kompendium nauki społecznej Kościoła, Kielce 2005.

Sandel M.J., Sprawiedliwość. Jak postępować stusznie?, Warszawa 2013.

Sanetra W., Dialog społeczny jako element ustroju społecznego i politycznego w świetle Konstytucji RP, [w:] Zbiorowe prawo pracy XXI wieku, red. A. Wypych-Żywicka, M. Tomaszewska, J. Stelina, Gdańsk 2012.

Seweryński M., Pojęcie, zakres i próba kodyfikacji zbiorowego prawa pracy w Polsce, [w:] Aktualne problemy zbiorowego prawa pracy w Polsce i w Niemczech, red. G. Goździewicz, Torun 2012.

Seweryński M., Dialog społeczny, [w:] Referaty na VI Europejski Kongres Prawa Pracy i Zabezpieczenia Społecznego, Warszawa 1999.

Seweryński M., Dylematy prawnej ochrony pracy, [w:] Z zagadnień prawa pracy i prawa socjalnego. Księga jubileuszowa Profesora Herberta Szurgacza, red. Z. Kubot, T. Kuczyński, Warszawa 2011.

Seweryński M., Problemy legislacyjne zbiorowego prawa pracy, [w:] Prawo pracy RP w obliczu przemian, red. M. Matey-Tyrowicz, T. Zieliński, Warszawa 2006.

Seweryński M., Problemy rekodyfikacji prawa pracy, [w:] Prawo pracy a wyzwania XXI wieku. Księga jubileuszowa Profesora Tadeusza Zielińskiego, red. M. Matey-Tyrowicz, L. Nawacki, B. Wagner, Warszawa 2002.

Seweryński M., Uwagi o efektywności prawa pracy, [w:] Księga pamiątkowa w piąta rocznice śmierci Profesora Andrzeja Kijowskiego, red. Z. Niedbała, Warszawa 2010. 
Koncepcja dobra wspólnego według Jana Pawła II...

Słomski W., Wielkość aksjologii, bogactwo czy zagrożenie?, [w:] Aksjologia wspótczesności. Problemy i kontrowersje, red. B. Truchlińska, Lublin 2012.

Sobczyk A., Daszyńska A., Dialog społeczny jako narzędzie zbiorowego prawa pracy, [w:] Dialog społeczny w praktyce przedsiębiorstw, red. J. Stelina, Gdańsk 2010.

Sobczyk A., Prawo pracy w świetle Konstytucji RP, t. I, Warszawa 2013.

Stawrowski Z., Dobro wspólne a filozofia polityki, [w:] Dobro wspólne. Teoria i praktyka, red. W. Arnold, ks. F. Longchamp de Berier, Warszawa 2013.

Szubert W., Problemy pracy w koncepcjach programowych Delegatury Rządu na Kraj (19411945), Łódź 2012.

Szubert W., Wspótczesne tendencje przemian w prawie pracy, „Państwo i Prawo” 1981, nr 8.

Wojtyła K., Osoba i czyn, Kraków 1969.

Wratny J., Kodeks pracy - układy zbiorowe pracy, [w:] Zbiorowe prawo pracy, red. J. Wratny, K. Walczak, Warszawa 2009.

Wronikowska E., Dialog społeczny jako podstawowa zasada zbiorowego prawa pracy w Polsce, Studia z zakresu prawa pracy i polityki społecznej, red. A. Świątkowski, Kraków 2007.

Wyka T., Partycypacja pracownicza w świetle nauczania Jana Pawła II, [w:] Studia z prawa pracy. Księga pamiątkowa ku czci Docenta Jerzego Logi, red. Z. Goral, Łódź 2007.

Wyka T., W poszukiwaniu aksjologii prawa pracy - o roli encykliki "Laborem exercens" Jana Pawta II, „Monitor Prawa Pracy” 2011, nr 9.

Wyka T., Znaczenie prawa o układach zbiorowych pracy dla pozaukładowych porozumień zbiorowych, [w:] Prawo pracy. Refleksje i poszukiwania. Ksiegga jubileuszowa Profesora Jerzego Wratnego, Warszawa 2013.

Zieliński T., Podstawy rozwoju prawa pracy, ,Zeszyty Naukowe Uniwersytetu Jagiellońskiego". Prace pracownicze, [Kraków] 1988, z. 120.

Zieliński T., Zbiorowe spory pracy a wspótczesne koncepcje ładu społecznego, „Ruch Prawniczy, Ekonomiczny i Socjologiczny" 1984, z. 2.

\section{The Concept of the Common Good According to John Paul II - the Implications for Collective Labour Law}

\section{Summary}

The author presents the view that collective labour law values are, inter alia, derived from the achievements of the social doctrine of the Catholic Church. One of such values is the common good. John Paul II refers to it many times. According to Him it is a personal value that liberates from selfishness and vested interests. The essence of collective labour law is based on a sense of the common good category, understood as a right expressing a compromise between different interests. Means to implement that common good which leads to social peace is a social dialogue. There are many regulations aimed at a social dialogue, in particular, the provisions specifying the procedure for conducting negotiations in order to conclude a collective agreement. 